\section{Analisis Kebijakan Penerimaan Pengungsi Suriah Oleh Kanada Pada Masa PM Trudeau}

Frequency of International Relations

Vol 1 (2) 285-313

(C) The Author(s)

fetrian.fisip.unand.ac.id

Submission track :

Submitted : August 30, 2019

Accepted : February 23, 2020

Available On-line : February 24, 2020

\author{
Ressa Fatika Eldiati \\ Universitas Andalas \\ ressa_fatika@yahoo.com
}

\begin{abstract}
This research will analyze Canadian policy in accepting Syrian refugees during the Trudeau period. This Canadian policy has become controversial given the issue of terrorism that is currently highlighted in the international world that these refugees could carry the threat of terrorism to other countries that result in these countries decided to reject refugees. However, despite with all of these issues Canada under the leadership of Trudeau actually decided to make a policy to accept the refugees that come to their country. This policy is completely different from the previous government which decide to reduce the entry of refugees to Canada. This research is an explanatory research through internet-based literature. Trudeau's policy in accepting Syrian refugees will be analyzed using the concept of determinants of foreign policy by William D. Coplin. There are four determinants that influence a country's foreign policy, which is, the international context, decision makers, domestic politics, and the economy and the military. This study found that of the four determinants, Canada's policy of accepting Syrian refugees during the Trudeau period was strongly influenced by public opinion in domestic political determinants, public opinion regarding the handling of refugees by Canada that had emerged since the election campaign in Canada and was Led by Trudeau to win the general election and economic conditions, Canadian needs for labour which drive the implementation of this policy
\end{abstract}

Keywords: Policy; Syria; Refugees; Canada; Trudeau 


\section{Pendahuluan}

Setiap tahun populasi pengungsi di seluruh dunia terus mengalami peningkatan. Penyebabnya adalah adanya perlakuan yang melanggar nilai-nilai kemanusiaan yang mereka terima di negaranya seperti penganiayaan dan kejahatan perang (Simeon, 2010). Kondisi tersebut mendorong mereka meninggalkan negaranya untuk mencari perlindungan. Permasalahan baru muncul bagi para pengungsi yaitu penolakan oleh negara tujuan terhadap pengungsi tersebut. Alasan dari penolakan negara tujuan tersebut antara lain seperti negara yang merasa tidak bertanggung jawab dalam menerima pengungsi karena tidak meratifikasi Konvensi 1951 dan Protokol 1967 yang berada dibawah UNHCR (United Nations High Commisioner for Refugee), sebuah badan dibawah PBB yang bertanggung jawab terhadap pengungsi. Alasan lain adalah adanya ancaman terhadap stabilitas keamanan negara yang disebabkan oleh perbedaan budaya dan ideologi serta resiko penyebaran konflik dari negara asal pengungsi (Kompasiana, 2018). Selain itu, negara kecil dan negara miskin menilai menerima pengungsi justru akan merugikan bagi negaranya karena kondisi geografis dan ekonomi negaranya yang dinilai tidak cukup memadai dalam menampung pengungsi.

Penolakan inilah yang terjadi kepada pengungsi Suriah yang berupaya mendapatkan perlindungan akibat konflik yang terjadi di negaranya. Menurut UNHCR pada tahun 2015, Suriah merupakan negara dengan angka penyumbang pengungsi tertinggi di dunia. Sejak perang saudara meletus di Suriah pada 2011, terdapat sekitar 5,6 juta orang dari negara tersebut yang mengungsi untuk menyelamatkan diri dan mendapatkan perlindungan. Negara-negara di Benua Eropa dan Amerika menjadi tujuan kebanyakan para pengungsi tersebut. Namun tidak semua negara tujuan yang kemudian mau menerima para pengungsi tersebut (UNHCR, 2018). 
Penolakan terhadap pengungsi asal Suriah oleh negara tujuan disebabkan mekanisme masuknya pengungsi ini tidak memiliki jaminan keamanan. Negara-negara di Eropa Timur seperti Polandia, Hungaria, Ceko, Rumania, dan Slovakia menganggap meningkatnya jumlah pengungsi yang masuk merupakan ancaman bagi kedaulatan mereka karena tidak semua negara mampu menampung pengungsi Suriah tersebut. Meskipun dalam hal ini Uni Eropa telah memberlakukan kuota wajib bagi negara anggotanya untuk menerima pengungsi. Pemberlakuan kuota wajib dinilai hanya akan mendorong semakin banyaknya pengungsi menjadikan negara-negara Eropa sebagai tujuannya (Bonasir, 2018).

Selain negara-negara Eropa, Amerika Serikat (AS) juga merupakan salah satu negara yang menolak masuknya pengungsi Suriah. AS dibawah Presiden Trump mengeluarkan kebijakan untuk menolak masuknya pengungsi Suriah tanpa batas waktu yang ditentukan ke AS. Kebijakan Trump ini merupakan respon terhadap serangan teror yang terjadi di Paris pada 13 November 2015 dimana salah satu dari tujuh pelaku yang tewas dalam serangan tersebut adalah warga Suriah yang masuk ke Eropa melalui Yunani dalam rombongan pengungsi. Hal ini dilakukan untuk mencegah terjadinya aksi teror yang sama di AS (BBC, 2018).

Berbeda dengan beberapa negara diatas yang menolak masuknya pengungsi Suriah ke negara mereka meskipun negara tersebut meratifikasi konvensi dan protokol tentang pengungsi, Kanada justru menyambut baik masuknya pengungsi Suriah. Keterlibatan Kanada dalam penanggulangan masalah pengungsi memang terus meningkat pasca meratifikasi konvensi dan protokol tentang pengungsi. Salah satunya adalah keberhasilan Kanada menampung sekitar 40.271 pengungsi Indocina pada tahun 1980. Namun, pada masa pemerintahan Perdana Menteri Stephen Harper yang menjabat sejak 
tahun 2006-2015, peran Kanada dalam penanggulangan pengungsi dinilai tidak terlalu baik. Kebijakan mengenai pengungsi pada masa Harper mengalami kemunduran dengan dipersulitnya pengungsi untuk masuk ke Kanada. Hal ini karena adanya ketakutan dari Partai Konservatif dalam isu keamanan ketika Kanada menampung terlalu banyak pengungsi (Amdjad, 2018).

Terpilihnya Trudeau sebagai Perdana Menteri baru Kanada pada akhir tahun 2015 membawa kebijakan baru yang lebih terbuka terhadap masuknya pengungsi Suriah. Sikap Kanada yang kembali terbuka untuk menerima pengungsi di negaranya dinilai sebagai salah satu bentuk peran aktif Kanada sejak terlibat dalam rezim pengungsi dibawah UNHCR. Kanada sendiri telah menandatangani konvensi mengenai status pengungsi 1951 dan protokol pengungsi 1967 pada 4 Juni 1969. Hal ini diwujudkan dengan masuknya sekitar 39.000 pengungsi Suriah ke Kanada hingga awal Januari 2016. Kebijakan Trudeau yang pro-pengungsi ini sendiri merupakan wujud dari janjinya pada masa kampanye. Pemerintahan Trudeau sendiri menargetkan sekitar 330.000 orang imigran untuk masuk ke Kanada pada 2017 (Tagva, 2018).

Kebijakan Kanada dalam meningkatkan penerimaan pengungsi Suriah tentu diiringi dengan meningkatnya anggaran yang dihabiskan. Kanada telah menghabiskan setidaknya 413 juta Dollar per tahun untuk 40.000 pengungsi yang telah masuk ke negara mereka antara tahun 2016 sampai 2017. Jumlah ini tentu terus meningkat seiring dengan semakin bertambahnya pengungsi Suriah yang masuk ke Kanada. Termasuk biaya relokasi, tempat tinggal, kesehatan dan edukasi, rata-rata pengungsi Suriah ini akan membutuhkan dana setidaknya 4000 dolar per orang per tahun (Coyle, 2018). 
Kebijakan Kanada menerima pengungsi Suriah ini bahkan mengabaikan ancaman terorisme yang justru menjadi ketakutan dari beberapa negara dalam menerima pengungsi asal Timur Tengah. Terlebih pasca terjadinya serangan di Paris dan San Bernardino yang melibatkan pengungsi Suriah. Ditambah dengan ancaman krisis pengungsi dan pengaruhnya terhadap kestabilan ekonomi negara. Merujuk pada fakta-fakta tersebut, menjadi unik untuk melihat kebijakan Kanada yang justru menerima pengungsi Suriah ditengah penolakan dari berbagai negara pada masa PM Trudeau tersebut. Oleh karena itu penulis merasa penting untuk membuat sebuah penelitian dengan mengangkat judul "Analisis Kebijakan Penerimaan Pengungsi Suriah Oleh Kanada Pada Masa PM Trudeau".

\section{Metode Penelitian}

Kebijakan luar negeri menurut Walter Carlsnaes yaitu, tindakan-tindakan yang diarahkan pada tujuan, kondisi, aktor (pemerintah maupun non pemerintah) yang berada di luar wilayah teritorial yang dilakukan oleh wakil-wakil pemerintah atau komunitas yang berdaulat. Menurut Mark Amstutz, kebijakan luar negeri merupakan tindakan pemerintah yang ditujukan untuk kepentingan nasionalnya yang melampaui batas wilayah negaranya (Amstutz, 2013). Sedangkan menurut Modelski, kebijakan luar negeri adalah strategi digunakan pemerintah negara terkait tindakan dan hubungannya dengan negara lain maupun unit politik internasional lainnya dalam mencapai kepentingan nasional (Modelski, 2016). Sehingga bisa disimpulkan bahwa kebijakan luar negeri merupakan tindakan yang dilakukan oleh negara terhadap pihak-pihak yang berada di luar teritorialnya untuk mencapai kepentingan nasionalnya. Terkait kebijakan Kanada dalam menerima pengungsi Suriah pada masa Trudeau sendiri, kebijakan ini dilakukan oleh pemerintah Kanada dibawah Trudeau ditujukan terhadap pengungsi Suriah dalam upaya 
mencapai kepentingan nasional Kanada. Dalam penelitian ini peneliti menggunakan konsep Determinan Politik Luar Negeri menurut William D. Coplin dalam bukunya yang berjudul "Introduction of International Politic".

Menurut Coplin, kebijakan luar negeri suatu negara dibentuk atas pengaruh dari berbagai pertimbangan yang ada di dalamnya. Coplin menjelaskan terdapat empat determinan yang mempengaruhi kebijakan luar negeri satu negara yaitu; konteks internasional, perilaku pengambil keputusan, kondisi ekonomi dan militer, dan politik dalam negeri (Coplin, 2013).

\section{Konteks Internasional}

Konteks internasional akan menjelaskan tentang bagaimana negara berperilaku yang akan ditentukan oleh sistem internasional dan hubungan negara tersebut dengan kondisi yang ada dalam sistem internasional tersebut. Kondisi internasional merupakan seperangkat faktor yang mempengaruhi politik luar negeri satu negara. Dalam hal ini terdapat tiga elemen penting dari konteks internasional yang mempengaruhi politik luar negeri yaitu geografis, ekonomis, dan politis.

Geografis di masa melihat bagaimana negara yang saling berdekatan menyatukan kekuatan dalam menghadapi ancaman atau justru satu negara akan memperluas wilayahnya ke negara terdekat. Geografis saat ini lebih kepada hubungan antar negara dalam kedekatan geografis seperti dalam perdagangan dan menjadi alasan utama dalam dibentuknya organisasi lintas negara dalam suatu kawasan.

Ekonomi dalam konteks internasional melihat aktivitas ekonomi melalui pertukaran barang dan jasa serta arus modal untuk menunjukkan kekuatan ekonomi yang dimiliki satu negara dan 
seberapa jauh negara tersebut bergantung terhadap negara lain. Negara maju akan menghadapi tekanan ekonomi yang berbeda dibanding negara terbelakang yang cenderung lebih bergantung kepada negara maju.

Hubungan politik antar negara memiliki pengaruh terhadap keputusan dalam kebijakan luar negeri satu negara. Aliansi yang terbentuk memiliki pengaruh tidak hanya bagi negara non-anggota namun juga anggotanya sendiri. Terdapat kondisi yang harus diperhitungkan dalam membuat keputusan terkait keterlibatan satu negara dalam aliansi. Selain itu, kemampuan dalam mendapatkan dukungan negara lain atas suatu kondisi juga akan mempengaruhi dibuatnya keputusan dalam kebijakan luar negeri dari negara tersebut.

\section{Pengambil Keputusan}

Perilaku politik suatu negara dianggap sebagai cerminan dari perilaku pemimpin terkait aktivitas politik luar negeri negara tersebut. Kepribadian dan perilaku individual dalam politik luar negeri dinilai mempengaruhi sikap pengambil keputusan dalam setiap keputusan yang dibuatnya. Namun, pengambil keputusan tidak dapat bergerak atas kemampuannya sendiri melainkan juga dipengaruhi oleh lingkungannya. Lingkungan tersebut adalah sistem internasional dan kondisi sosial dan politik dalam negerinya yang kemudian menjadi hambatan dan hal-hal yang membatasi aktivitas pengambil keputusan tersebut.

\section{Politik Dalam Negeri}

Dalam determinan ini, keputusan politik luar negeri suatu negara akan dipengaruhi oleh stabilitas sistem politik dari negara tersebut. Negara dengan sistem politik terbuka atau negara demokrasi akan cenderung untuk berargumentasi di publik tentang kebijakan 
dalam aktivitas politik luar negerinya. Sedangkan negara dengan sistem politik tertutup atau negara otokratis akan mencapai konsensus secara individu.

Selain itu, masyarakat juga menjadi aspek yang mempengaruhi dalam perumusan kebijakan luar negeri terkait politik dalam negeri negara tersebut. Menurut Rosenau sumber ini mencakup budaya, sejarah, pembangunan ekonomi, struktur sosial dan perubahan opini publik. Budaya dan sejarah akan mencakup nilai, norma, tradisi, dan pengalaman masa lalu. Struktur sosial mencakup sumber daya manusia yang dimiliki suatu negara termasuk harmoni dan konflik sosial didalamnya. Sedangkan opini publik adalah perubahan sentimen masyarakat atas suatu fenomena.

\section{Kondisi Ekonomi dan Militer}

Ekonomi dan militer merupakan dua hal yang saling berkaitan. Ketika kemampuan militer meningkat, maka akan meningkatkan kemakmuran ekonomi suatu negara. Begitupun, ketika kemampuan ekonomi semakin kuat maka akan ada peningkatan pada kekuatan militernya. Kemampuan ekonomi dan militer berpengaruh terhadap pengambil keputusan terkait tuntutan dan dukungan terhadap kebijakan luar negeri yang akan dibuat. Negara dengan ekonomi dan militer yang baik akan lebih mampu untuk menyeimbangkan antara kepentingan nasional yang ingin dicapainya dengan kapabilitas negara itu sendiri.

\section{Pembahasan}

Empat determinan yaitu, konteks internasional, pengambil keputusan, politik dalam negeri, serta ekonomi dan militer yang dikemukakan Coplin, akan menjabarkan hal yang menjadi pertimbangan dalam pembuatan kebijakan di Kanada sehingga 
kemudian menghasilkan efek politik yaitu, keputusan Kanada menerima pengungsi Suriah.

\section{Determinan Konteks Internasional}

Konteks internasional menjelaskan bagaimana negara berperilaku yang dipengaruhi oleh sistem internasional dan kondisi di dalam sistem internasional tersebut. Pada dasarnya terdapat tiga elemen penting dalam konteks internasional ini, yaitu geografis, ekonomis, dan politis. Melalui tiga elemen ini kemudian dapat dilihat peristiwa internasional serta aktor eksternal yang berpengaruh dalam pengambilan kebijakan di Kanada.

Geografis menurut konteks internasional yang akan dibahas terkait kebijakan Kanada dalam menerima pengungsi Suriah ini adalah jarak. Suriah ke Kanada memiliki jarak sekitar 9.380 kilometer melintasi Samudra Atlantik Utara, yang mana Suriah berada di benua Asia sedangkan Kanada merupakan bagian dari Amerika Utara (Statista, 2019). Namun, jarak yang cukup jauh ini tidak menghalangi keinginan pengungsi Suriah untuk masuk ke Kanada. Dapat dilihat dari pengungsi Suriah yang berada pada posisi tujuh teratas pada tahun 2016 untuk permohonan status pengungsi di Kanada. Selain itu, untuk membawa pengungsi Suriah masuk ke Kanada, pemerintah Kanada juga telah menyiapkan penerbangan seperti pesawat militer serta pesawat komersial yang telah disewa pemerintah Kanada untuk membawa pengungsi Suriah dari kamp-kamp pengungsi yang ada di Lebanon, Jordan, dan Turki. Kanada sendiri mengutamakan untuk membawa pengungsi Suriah yang telah berada di kamp pengungsian di luar Suriah yang telah melalui proses penyaringan untuk masuk ke Kanada (Galloway, 2019).

Ekonomi dalam konteks internasional dapat dilihat dari seberapa tingkat ketergantungan suatu negara dalam memenuhi 
kebutuhan masyarakatnya terhadap negara lain. Arus barang dan jasa serta arus modal menjadi tolak ukur dalam melihat kekuatan ekonomi suatu negara. Terkait hubungan ekonomi, Suriah bukan merupakan mitra yang cukup penting dalam ekonomi Kanada. Suriah sendiri berada pada peringkat 108 mitra dagang bagi Kanada (Workman, 2019). Aktivitas ekspor impor Suriah secara umum hanya bergerak disekitar negara tetangganya seperti Libanon dan Turki. Kanada sendiri memiliki sumber daya alam yang melimpah yang mampu menopang perekonomian negaranya. Kanada dikenal sebagai anggota G7 yang merupakan tujuh negara dengan ekonomi terdepan di dunia. Sedangkan Suriah berada di peringkat 157 dalam ekonomi dunia. Bahkan Kanada pernah memberikan sanksi dagang kepada Suriah terkait krisis kemanusiaan dan penggunaan senjata kimia dalam konflik Suriah. Bisa disimpulkan hubungan dagang Kanada terhadap Suriah tidak berada dalam posisi yang strategis bagi ekonomi di Kanada. Sehingga terkait kebijakan penerimaan pengungsi Suriah oleh Kanada elemen ekonomi dalam konteks internasional ini tidak terlalu berpengaruh terhadap kebijakan yang dilakukan oleh Kanada (OEC, 2019).

Politik dalam konteks internasional dapat dilihat dari keterlibatan suatu negara dalam aliansi ataupun organisasi internasional. Kanada dalam hal ini merupakan salah satu negara yang meratifikasi konvensi 1951 dan protokol 1967 terkait pengungsi dibawah UNHCR. Berdasarkan mandat UNHCR, Kanada berkewajiban untuk menampung dan memberi perlindungan kepada pengungsi. Hal ini berdasarkan prinsip non-refoulement dalam Bab V Pasal 33 Konvensi 1951 tentang status pengungsi yang melarang negara tujuan untuk mengusir ataupun mengembalikan pengungsi ke daerah yang dapat mengancam kehidupan dan kebebasannya. Kanada sendiri telah melampaui kewajibannya sebagai negara yang meratifikasi konvensi 
tersebut (UNHCR, 2019). Kanada tidak hanya berkomitmen dalam menampung pengungsi akan tetapi juga berupaya memukimkannya kembali di Kanada.

Dapat disimpulkan bahwa kebijakan Kanada dalam menerima pengungsi Suriah dilihat dari faktor geografis dalam konteks internasional, berdasarkan jarak yang cukup jauh antara Suriah dan Kanada tidak menghalangi keinginan pengungsi untuk masuk ke Kanada. Hal ini dikarenakan Kanada yang menjemput sendiri pengungsi tersebut menggunakan penerbangan yang telah disiapkan dari kamp pengungsi di sekitar Suriah. Sedangkan dalam faktor ekonomi, Kanada merupakan salah satu negara dengan ekonomi terdepan di dunia dan secara khusus tidak memiliki hubungan ekonomi yang cukup penting dengan Suriah bahkan Kanada justru melakukan embargo ekonomi terhadap Suriah. Oleh karena itu, kebijakan Kanada dalam menerima pengungsi Suriah tidak terlalu dipengaruhi oleh hubungan ekonomi kedua negara. Terakhir berdasarkan faktor politik, yaitu Kanada yang memiliki kewajiban dalam menerima pengungsi sebagai negara pihak yang meratifikasi konvensi dan protokol tentang pengungsi. Maka hal ini merupakan salah satu hal yang mendorong Kanada untuk menerima pengungsi Suriah dilihat dari determinan konteks internasional.

\section{Determinan Pengambil Keputusan}

Perilaku pengambil keputusan dalam proses pembuatan kebijakan dalam hal ini dilakukan oleh Perdana Menteri Kanada yaitu Justin Trudeau akan mencerminkan kebijakan yang diambil oleh Kanada sebagai negara. Kepribadian, nilai yang dianut serta gaya politik Trudeau merupakan hal-hal yang akan mempengaruhi keputusan yang akan diambil. 
Proses pembuatan kebijakan di Kanada, dilakukan oleh kabinet di bawah pimpinan Perdana Menteri dan Menteri Luar Negeri, dan Menteri bidang yang bersangkutan. Lebih jauh dalam prakteknya akan melibatkan interaksi dengan elit politik seperti kelompok kepentingan dan birokrat serta pengaruh dari opini publik di Kanada. Wewenang dari Perdana Menteri sendiri sebenarnya tidak diatur dalam hukum atau konstitusi apapun di Kanada. Namun, merujuk pada Constitution Act 1867 sebagai dasar dalam membentuk negara Kanada modern serta pemerintahannya seperti yang dikenal sekarang ini, Perdana Menteri memiliki peran paling kuat dalam politik Kanada.

Bagan 1: Pembuat Kebijakan di Kanada

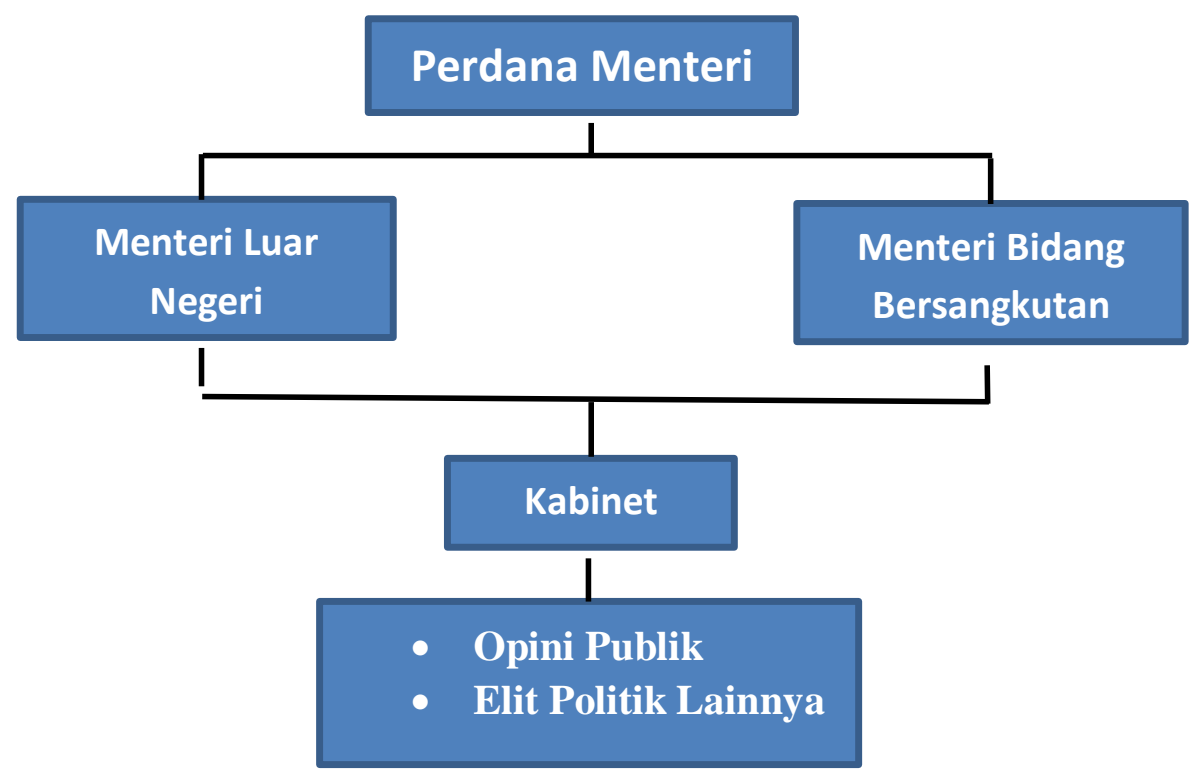

Sumber: Howard H. Lentner, Foreign Policy Decision Making: The Case of Canada And Nuclear Weapons

Justin Trudeau menjadi perdana menteri Kanada pada tahun 2015 setelah memenangkan pemilihan umum di Kanada mengalahkan Stephen Harper dari Partai Konservatif. Trudeau menyatakan akan menanamkan nilai tradisional Kanada dalam pemerintahannya melalui penyelenggaraan jaminan kesehatan dan pendidikan, menjaga 
perdamaian serta tidak memiliki nuklir di Kanada. Trudeau yang memiliki latar belakang dalam bidang pendidikan kemudian juga membuatnya fokus terhadap pendidikan di Kanada. Menurut Trudeau pendidikan merupakan instrumen sosial yang tepat bagi Kanada saat ini untuk mendorong perubahan pola pikir. Perubahan pola pikir masyarakat Kanada melalui pendidikan ini menurutnya penting untuk melibatkan orang-orang muda di Kanada dalam proses politik dan keterlibatan dalam aktivitas sosial serta mendorong mereka untuk menyadari tanggung jawabnya dalam masyarakat demokratis. Peningkatan pendidikan dalam masyarakat Kanada ini kemudian menjadi salah satu yang mendorong partisipasi publik Kanada terkait kebijakan Kanada dalam menerima pengungsi Suriah. Dalam aktivitas sosialnya, keterlibatan masyarakat Kanada dalam penanganan pengungsi Suriah ini juga dapat dilihat dari banyaknya sukarelawan dan donasi yang dilakukan warga Kanada (Gatehouse, 2019).

Selain hal-hal yang melekat pada diri Trudeau sebagai Perdana Menteri Kanada yang mendorong kebijakan untuk menerima pengungsi Suriah di Kanada. Kebijakan penerimaan pengungsi Suriah di Kanada juga didukung oleh partai pengusung Trudeau yaitu Liberal. Pada masa kampanye, Trudeau dan Liberal, berjanji untuk melakukan perubahan terhadap sembilan tahun pemerintahan Konservatif di Kanada. Salah satunya dengan menerima pengungsi Suriah yang sebelumnya tidak terjadi pada masa Harper. Janji kampanye inilah yang kemudian berhasil direalisasikan oleh Trudeau ketika berhasil memenangkan pemilu Kanada dan menjadi perdana menteri.

Berdasarkan penjelasan di atas, Trudeau sebagai pengambil keputusan utama dalam kebijakan Kanada menerima pengungsi Suriah dipengaruhi oleh hal-hal yang melekat pada dirinya seperti kepribadian dan nilai-nilai yang dianutnya. Trudeau yang memiliki latar belakang di bidang pendidikan fokus pada peningkatan 
pendidikan masyarakat Kanada untuk peningkatan partisipasi politik dan aktivitas sosial masyarakat Kanada. Sehingga hal ini kemudian juga berpengaruh terhadap pola pikir masyarakat Kanada terkait permasalahan pengungsi Suriah di Kanada. Selain itu, Partai Liberal sebagai partai pengusung Trudeau serta pembuat kebijakan yaitu kabinet turut mempengaruhi pengambilan keputusan oleh Trudeau terkait kebijakan penerimaan pengungsi Suriah di Kanada.

\section{Determinan Politik Dalam Negeri}

Kanada sebagai negara yang demokratis menjamin hak bagi warga negaranya untuk berpartisipasi dalam politik baik secara langsung maupun tidak langsung terkait keputusan yang akan mempengaruhi mereka. Kanada menerapkan sistem demokrasi parlementer yang berupaya untuk mengakomodasi realita geografis yang luas beserta keanekaragaman masyarakatnya. Oleh karena itu, masyarakat beserta aspek seperti sejarah, budaya, dan opini publik akan mempengaruhi proses pembuatan kebijakan di Kanada, salah satunya kebijakan penerimaan pengungsi Suriah.

Kebijakan Kanada dalam menerima pengungsi Suriah, tidak terlepas sejarah dan budaya Kanada terkait pengungsi. Seperti yang pernah dijelaskan sebelumnya, peran Kanada dalam menerima pengungsi ini telah ada sejak abad 18 yang mana pada saat itu Kanada dimasuki gelombang pengungsi yang sangat besar akibat dari revolusi Amerika. Pasca perang dunia kedua, Kanada juga dimasuki sekitar 37 ribu pengungsi Hungaria tepatnya pada tahun 1956-1957. Pada akhir 1970-an Kanada juga menerima pengungsi manusia perahu dari Vietnam sekitar lebih dari 60 ribu orang. Selanjutnya Kanada juga menerima pengungsi dari berbagai belahan dunia lain seperti Uganda, Kosovo, dan negara-negara lainnya (Mc Callum, 2019). 
Sejarah Kanada yang sangat terbuka dengan pengungsi, menjadikan Kanada kemudian dikenal sebagai bangsa migran di dunia. Kanada menjadi salah satu negara dengan ras dan etnis paling beragam. Keanekaragaman yang terdapat di Kanada ini kemudian mendorong kerukunan antar ras dan etnis serta pemahaman lintas budaya di negara ini. Bahkan dalam menjaga keanekaragaman di Kanada ini untuk tidak menimbulkan perpecahan, Pierre Trudeau menjadikan Multikulturalisme sebagai salah satu kebijakan resmi di Kanada pada tahun 1971. Saat itu, Kanada menjadi negara pertama di dunia yang mengadopsi multikulturalisme sebagai kebijakan resmi. Kebijakan ini ditujukan agar semua warga Kanada dapat menjaga identitas mereka dan melindungi serta melestarikan keragaman yang ada di Kanada.

Berdasarkan sejarah panjang Kanada terkait penerimaan pengungsi serta perlindungan budaya multikultural yang berkembang di Kanada, mendorong terbentuknya opini publik Kanada terkait pengungsi Suriah. Publik menilai reputasi Kanada yang menurun terkait penanganan pengungsi sejak Konservatif berkuasa di Kanada. seperti yang telah dijelaskan sebelumnya, Kanada di bawah Harper hanya menerima sekitar 115 ribu dari 20 juta pengungsi dunia yang tercatat di UNHCR selama pemerintahannya. Bahkan untuk pengungsi Suriah, Kanada hanya menerima sekitar 2.300 dari sekitar 4 juta total pengungsi Suriah. Ditambah dengan viralnya foto Alan Kurdi yang meninggal di Pantai Turki dalam upaya masuk ke Kanada namun ditolak oleh pemerintah Kanada. Sehingga publik Kanada mulai mempertanyakan sejarah hebat Kanada dalam menerima pengungsi serta semangat multikultural di Kanada (Fong, 2019).

Menurunnya peran Kanada terkait penanganan pengungsi terutama pengungsi Suriah pada masa Harper memunculkan polemik di kalangan masyarakat Kanada sendiri. Namun, sebagian besar masyarakat Kanada tetap mendukung pemerintah untuk menerima 
lebih banyak pengungsi Suriah ke negara mereka. Sehingga masalah pengungsi Suriah ini tetap menjadi salah satu isu penting dalam masa kampanye pemilihan umum Kanada. Para kandidat kemudian berupaya untuk menjadikan penerimaan pengungsi Suriah sebagai kebijakan yang akan mereka prioritaskan dalam janji politik mereka ketika terpilih nanti. Dimulai dari Stephen Harper yang menjanjikan menerima 10 ribu pengungsi Suriah pada 2017 jika terpilih kembali dan Trudeau yang menjanjikan 25 ribu pengungsi Suriah pada 2016 (CBC, 2019).

Janji politik terkait penerimaan pengungsi Suriah yang dilontarkan calon Perdana Menteri dalam masa kampanye pemilihan umum Kanada, tentu tidak terlepas atas pengaruh dari partai politik yang pendukungnya. Dalam sistem politik di Kanada sendiri, Perdana Menteri yang terpilih merupakan ketua partai yang memenangkan pemilihan umum dewan perwakilan rakyat (House of Commons) di Kanada. Sedangkan partai yang berada di posisi kedua akan menjadi oposisi resmi pemerintah. Jumlah partai yang terdaftar di Kanada sendiri cukup banyak, tercatat pada pemilu 2015 terdapat 23 partai politik yang terdaftar. Namun tidak semua partai dapat memenangkan kursi di pemilihan. Hal ini tidak terlepas dari dominasi dua partai besar dalam politik Kanada yaitu Konservatif dan Liberal (Canada Guide, 2019).

Partai liberal telah mendominasi sebagian besar sejarah politik di Kanada. Liberal telah berhasil berperan besar dalam mengatur pemerintahan di Kanada sejak akhir 1890-an dan juga memimpin di Kanada melalui 10 Perdana Menterinya. Secara tradisional, Liberal disebut sebagai partai "broker" atau penghubung terkait dengan keberhasilannya dalam mengangkat berbagai isu kepentingan berdasarkan pada wilayah, bahasa, suku, dan kelas sosial dalam pemerintahan Kanada. Partai ini berasal dari kelompok oposisi 
reformis terhadap pemerintahan Kanada pada pertengahan abad ke-19 (Rayside, 2019).

Terkait kebijakan penerimaan pengungsi Suriah di Kanada, dapat dilihat bahwa kebijakan ini turut dipengaruhi oleh adanya opini publik Kanada mengenai peran Kanada dalam bantuan terhadap pengungsi pada masa kampanye pemilihan umum di Kanada. Menguatnya isu pengungsi Suriah di kalangan publik Kanada, mendorong partai Liberal untuk menjadikan permasalahan ini sebagai salah satu bagian rencana reformasi kebijakan di Kanada untuk memenangkan hati warga Kanada dalam pemilihan umum. Dibandingkan Konservatif yang sebelumnya memerintah di Kanada yang dikenal sangat ketat dengan penerimaan pengungsi Suriah sehingga mengakibatkan menurunnya peran Kanada dalam bantuan bagi pengungsi.

Merosotnya jumlah penerimaan pengungsi di Kanada terutama pengungsi Suriah pada masa pemerintahan Harper tidak terlepas dari latar belakang Partai Konservatif yang mendukungnya. Konservatif menggambarkan dirinya sebagai partai yang menyukai pajak rendah, pemerintahan yang lebih kecil, rezim hukum dan ketertiban yang kuat, militer yang kuat serta penghormatan terhadap nilai-nilai tradisional. Di Kanada sendiri Konservatif dikenal sebagai partai yang memiliki pandangan tradisional mengenai hal-hal dalam kehidupan manusia seperti seks, gender, dan keluarga (Canada Guide, 2019).

Nilai-nilai tradisional yang dianut Konservatif dalam kegiatan politiknya salah satunya berujung pada munculnya sentimen antiimigran di Kanada. Konservatif tidak terlalu mendukung multikulturalisme di Kanada bahkan cenderung terlihat sebagai antiMuslim yang hanya mengutamakan masuknya imigran asal Eropa. Sehingga terkait dengan permasalahan pengungsi Suriah, Konservatif 
tidak terlalu terikat dengan tanggung jawab untuk membantu pengungsi tersebut (Dobbin, 2019).

Terpilihnya Trudeau sebagai perdana menteri Kanada pada akhir 2015 kemudian berhasil mendorong terealisasinya kebijakan tersebut dengan masuknya lebih dari 25 ribu pengungsi Suriah sampai akhir Februari 2016 ke Kanada. Bahkan masyarakat Kanada maupun organisasi non pemerintah yang bersedia untuk menjadi sponsor pribadi dalam menampung pengungsi Suriah di Kanada sebagai sukarelawan bagi pengungsi tersebut.

Berdasarkan penjelasan diatas disimpulkan bahwa, sejarah Kanada yang terbuka dengan masuknya imigran sejak abad ke-18 menjadikan Kanada sebagai bangsa yang memiliki keragaman etnis dan budaya. Keragaman ini memunculkan semangat multikulturalisme di Kanada yang kemudian diadopsi menjadi sebuah kebijakan pada 1971 untuk melindungi keberagaman tersebut. Namun, pada masa pemerintahan Stephen Harper dari Partai Konservatif, reputasi ramah pengungsi Kanada justru merosot tajam. Hal ini mendorong opini publik terkait peran Kanada dalam penanganan pengungsi terutama pengungsi asal Suriah. Sehingga masalah pengungsi ini menjadi salah satu isu penting dalam kampanye pemilihan umum di Kanada. Hal ini menjadikan Partai Liberal di bawah Trudeau menjanjikan untuk menerima 25 ribu pengungsi Suriah jika terpilih. Sedangkan Konservatif di bawah Harper juga mulai mengambil simpati publik terkait masalah pengungsi Suriah ini meskipun hanya mampu menjanjikan 10 ribu pengungsi Suriah untuk masuk ke Kanada jika terpilih kembali. Harper sendiri sebelumnya sangat tertutup terkait masalah pengungsi. Terpilihnya Trudeau sebagai Perdana Menteri baru Kanada dalam pemilu tersebut kemudian mendorong direalisasikannya kebijakan Kanada dalam menerima pengungsi Suriah. 


\section{Determinan Kondisi Ekonomi dan Militer}

Kondisi ekonomi dan militer dalam proses pembuatan kebijakan luar negeri merupakan dua hal yang saling berkaitan. Di sini didefinisikan bahwa ketika ekonomi meningkat maka militer juga akan meningkat begitu pun sebaliknya. Kondisi ekonomi dan militer suatu negara akan menjadi tuntutan dan dukungan dalam pembuatan kebijakan luar negeri.

Kanada dikenal sebagai salah satu negara maju dengan ekonomi sepuluh teratas dunia dan menjadi negara anggota G7. Pertumbuhan ekonomi yang baik di Kanada berasal dari aktivitas industri di negara tersebut. Terdapat tiga industri utama yang bergerak di Kanada yaitu, industri jasa, barang, dan sumber daya alam. Industri jasa yang bergerak dalam penyediaan pelayanan transportasi, kesehatan, pendidikan dan lain-lain. Industri barang menghasilkan produk seperti makanan, kertas, mesin, pakaian, dan lain-lain. Sedangkan industri sumber daya alam bergerak pada sektor energi, agrikultur, kehutanan, dan perikanan (Canada Government, 2019).

Industri sebagai salah satu sektor terbesar dalam kegiatan ekonomi Kanada, bergerak dalam berbagai bidang yang tentu saja membutuhkan jumlah pekerja yang tidak sedikit. Terus meningkatnya pertumbuhan ekonomi di Kanada nyatanya tidak sejalan dengan pemenuhan kebutuhan tenaga kerjanya. Kanada justru mengalami kekurangan tenaga kerja di tengah tingginya aktivitas industri negara tersebut. Salah satu data menyebutkan 1 dari 25 pekerjaan tidak dapat dipenuhi. Bahkan menurut laporan tahun 2014 dari Miner Management Consultants, kekurangan tenaga kerja di Kanada akan berlanjut sampai tahun 2031 yang diperkirakan Kanada akan kekurangan 2 juta pekerja pada tahun tersebut. Kekurangan tenaga kerja banyak terjadi di sektor pertanian dan agri-pangan, dengan 
jumlah sekitar 90 ribu kekurangan pada pertanian dan 32.500 pada pemrosesan makanan yang diperkirakan terjadi di 2015 (Kelly, 2019).

Tercatat jumlah pengangguran resmi di Kanada pada 2015, hanya berjumlah sekitar 7,3 persen. Yang mana jumlah ini muncul karena ketidaksesuaian lapangan kerja dengan harapan pencari kerja di Kanada. Alasan dari kurangnya tenaga kerja ini yaitu orang Kanada dengan penghasilan yang tinggi dan bekerja di sektor perminyakan enggan untuk pindah ke pedesaan dan bekerja di pabrik. Alasan lain adalah fenomena lain yaitu, tingginya tingkat pendidikan generasi muda di Kanada sehingga kemudian mereka tidak menemukan pekerjaan yang cocok dengannya. Tingkat pengangguran ini juga terus mengalami penurunan pada tahun-tahun berikutnya yaitu, 7\% pada 2016, 6.3\% pada tahun 2017, dan 5.8\% pada 2018 (Kelly, 2019).

Tingginya kebutuhan tenaga kerja sangat sulit dipenuhi oleh Kanada sendiri. Oleh karena itu, Kanada mendorong posisi tersebut untuk diisi oleh tenaga kerja asing. Bahkan pemerintah mulai meninjau kembali aturan tentang program pekerja asing sementara atau Temporary Foreign Worker Program (TFWP) untuk mempermudah pemenuhan tenaga kerja. Selain dengan menerima tenaga kerja asing, pengungsi yang masuk ke Kanada juga dianggap merupakan solusi dalam menangani permasalahan tenaga kerja di negara ini (Wangkhang, 2019).

Terkait masuknya pengungsi ke Kanada terutama pengungsi Suriah, dalam jangka pendek kebijakan ini akan dilihat sebagai tindakan kemanusiaan. Namun dalam jangka panjang hal ini justru akan bermanfaat bagi ekonomi Kanada. Dalam hal ini Kanada melihat keuntungan jangka panjang yang dapat diterima Kanada dibandingkan biaya jangka pendek yang dihabiskan dalam menampung pengungsi Suriah. Pengungsi yang menjadi pekerja di Kanada ini rata-rata 
memiliki upah yang lebih rendah dibandingkan imigran dari negara lainnya. Namun, mereka justru memiliki nilai ekonomi ketika mereka memenuhi kebutuhan tenaga kerja di Kanada.

Selain mampu membantu pemenuhan tenaga di Kanada, salah satu laporan dari Vancity Banking, menyebutkan bahwa pengungsi Suriah akan menghasilkan lebih dari US\$ 500 juta selama 20 tahun terhadap ekonomi setempat. Hal ini tentu merupakan keuntungan jangka panjang bagi Kanada dibandingkan biaya pemerintah keluarkan. Kebijakan untuk membawa pengungsi Suriah masuk ke Kanada menghabiskan dana sekitar US\$ 670 juta, jumlah tersebut hanya 0,2 persen dari anggaran Kanada. Untuk 6 tahun pertama, bahkan Kanada akan menghabiskan sekitar 1,2 miliar dolar untuk memukimkan kembali 25 ribu pengungsi Suriah di Kanada. Namun jumlah tersebut tentu sebanding dengan keuntungan yang diterima Kanada dalam jangka panjang melalui pemenuhan kebutuhan tenaga kerja dan peningkatan penerimaan pajak di Kanada ketika pengungsi berhasil dimukimkan kembali. Hal ini tentu akan terus mendorong pertumbuhan ekonomi di Kanada ( Tencer, 2019).

Dilihat dari segi militer, berbanding terbalik dengan ekonomi yang sangat maju, kekuatan militer Kanada justru berada pada posisi 21 dari 137 negara di dunia pada 2019. Tidak terlalu baiknya kekuatan militer Kanada dibanding negara anggota G7 yang lain berdasarkan pada sedikitnya jumlah tentara aktif di Kanada. jumlah tentara aktif di Kanada hanya sekitar 92 ribu personel. Selain itu, Kanada juga kekurangan pesawat pengangkut dan helikopter serang serta tank dan kapal selam. Pada 2018, Kanada sendiri hanya menghabiskan sekitar US\$ 19 milyar untuk militernya. Namun, Kanada masih ikut serta dalam beberapa operasi militer AS di Iraq dan Afghanistan sebagai bagian dari aliansi militer NATO. 
Tabel 1: Peringkat militer negara anggota G7

\begin{tabular}{|c|c|}
\hline Negara G7 & Peringkat \\
\hline Amerika Serikat & 1 \\
\hline Perancis & 5 \\
\hline Jepang & 6 \\
\hline Inggris & 8 \\
\hline Jerman & 10 \\
\hline Italia & 11 \\
\hline Kanada & 21 \\
\hline
\end{tabular}

Sumber: Global Fire Power, 2019, Military

Strength Ranking

Tidak terlalu baiknya militer di Kanada disebabkan oleh dua faktor yaitu rendahnya minat warga Kanada untuk bergabung dengan militer serta militer yang hanya difokuskan untuk melindungi perbatasan. Anak muda Kanada biasanya tidak terlalu akrab ataupun tertarik dengan militer, sehingga keterlibatan mereka dalam militer pun sedikit. Akibatnya jumlah tentara aktif di Kanada juga menjadi sedikit. Selain itu, pemerintah Kanada juga cenderung untuk memfokuskan militernya hanya untuk melindungi perbatasan. Bahkan dalam 120 tahun terakhir satu-satunya perang yang melibatkan Kanada adalah perang Korea. Namun perang ini juga tidak menimbulkan ketegangan politik yang signifikan bagi Kanada dan Korea (bercuson, 2019).

Terkait militer yang tidak terlalu baik, Kanada tetap memutuskan untuk menerima masuk pengungsi Suriah ke negara mereka meskipun terdapat ancaman terorisme yang menjadi ketakutan pemerintahan Kanada sebelumnya yaitu pada masa Stephen Harper. Untuk mengantisipasi masuknya teroris melalui jalur pengungsi ke Kanada, pemerintah Kanada bekerja sama dengan beberapa lembaga melakukan penyaringan terhadap pengungsi yang akan masuk ke 
Kanada. Pemeriksaan keamanan terhadap pengungsi yang akan masuk ke Kanada melibatkan CSIS (Canadian Security Intelligence Service) yaitu layanan intelijen keamanan Kanada dan RCMP (Royal Canadian Mounted Police) yaitu pasukan polisi federal dan nasional Kanada (CCR, 2019).

Pemeriksaan ini meliputi sidik jari dan wawancara dan menurut undang-undang imigrasi dan perlindungan pengungsi Kanada, pengungsi tersebut akan ditolak untuk masuk ke Kanada jika terbukti berkaitan dengan keamanan, tindakan kriminal serius, kejahatan terorganisir, dan pelanggaran HAM melalui pemeriksaan tersebut. Selain itu, pengungsi yang menjadi prioritas untuk diterima adalah wanita dan anak-anak. Sehingga meskipun memiliki militer yang tidak terlalu baik, hal ini tidak terlalu berpengaruh terhadap kebijakan Kanada dalam menerima pengungsi Suriah karena sistem pemrosesan pengungsi yang ketat oleh Kanada merupakan solusi untuk mencegah masuknya teroris melalui pengungsi Suriah ke Kanada (CCR, 2019).

Berdasarkan penjelasan di atas, dapat disimpulkan bahwa ekonomi Kanada yang beda pada posisi 10 teratas dunia dengan industri sebagai sektor utama meningkatkan kebutuhan tenaga kerja di Kanada. Namun, kebutuhan industri Kanada terhadap tenaga kerja belum mampu dipenuhi seluruhnya. Sehingga masuknya pengungsi Suriah merupakan salah satu solusi untuk memenuhi kebutuhan tersebut. Namun, berbanding terbalik dengan peningkatan ekonomi, kekuatan militer di Kanada justru berada pada posisi 21 di dunia. Hal ini tidak berpengaruh terhadap kebijakan Kanada dalam menerima pengungsi Suriah karena Kanada telah memiliki sistem pemrosesan yang menyaring pengungsi yang masuk ke Kanada.

\section{Kesimpulan}


Berdasarkan hasil analisis dalam penelitian ini dapat disimpulkan bahwa setiap determinan memiliki pengaruh masingmasing terhadap kebijakan penerimaan pengungsi Suriah oleh Kanada pada masa Trudeau. Namun, terdapat faktor yang dominan dari keempat determinan yang mempengaruhi kebijakan tersebut yaitu opini publik. Opini publik merupakan faktor yang dominan karena merupakan faktor penting yang mendorong terbentuknya kebijakan penerimaan pengungsi Suriah. Faktor opini publik ini bahkan telah muncul sejak masa kampanye pemilu yang mana kemudian dimanfaatkan oleh partai politik dan calon Perdana Menteri untuk memenangkan pemilu. Trudeau menjadikan kebijakan penerimaan pengungsi Suriah sebagai janji politik jika ia terpilih dan akhirnya direalisasikan ketika Trudeau berhasil memenangkan pemilu Kanada dan menjadi Perdana Menteri. Sedangkan ekonomi Kanada, yaitu kebutuhan Kanada yang sangat besar terhadap tenaga kerja menjadi faktor pendorong lainnya terkait dilaksanakannya kebijakan penerimaan pengungsi Suriah di Kanada setelah naiknya Trudeau sebagai Perdana Menteri Kanada.

\section{Daftar Pustaka}

Government of Canada . A History of Refugee. t.thn. https://www.canada.ca/en/immigration-refugees-citizenship/ servics/refugees/canada-role/timeline.html (diakses Desember 26, 2018)

Government of Canada. Guide to Candian Charter of Rights And Freedoms. t.thn. https://www.canada.ca/en/canadianheritage/services/how-rights-protected/guide-canadian-charterrights-freedoms.html (diakses Februari 21, 2019)

News Staff. Syrian Refugees Coming to Canada. t.thn. https://toronto.citynews.ca/2015/11/24/syrian-refugees-coming-tocanada-what-you-need-to-know/ (diakses Maret 25, 2019).

$\mathrm{BBC}$ news Indonesia . Pasca serangan Paris AS tolak pengungsi Suriah. t.thn. 
https://www.bbc.com/indonesia/dunia/2015/11/151117_dunia_amri k_pengungsisuriah (diakses Agustus 25, 2018).

Amdjad, Mudzakir. Kanada yang sama. 21 Oktober 2015. https://www.merdeka.com/khas/kanada-yang-sama.html (diakses Agustus 21, 2018).

Andrews. "Classic Grounded Theory to Analize Secondary data: Reality and Reflection." the grounded theory review vol.11, 2012: 5.

Anonymous. IRCC Facts And Figures 2014. t.thn. https://open.canada.ca/data/en/dataset/1d3963d6-eea9-4a4b-8e4a5c7f2deb7f29 (diakses Januari 29 , 2019).

- Top 10 Origin Countries of Persons claiminng Refugee Status in Canada in $2016 . \quad$ t.thn. https:/www.statista.com/statistics/549366/top-10-origincountries-of-refugee-claimants-in-canada/ (diakses April 3 , 2019).

- About Canada. thn.

http://www.studycanada.ca/indonesia/whycanada.htm (diakses Januari 15 , 2019).

- Brief history of Canada's responses to Refugees. t.thn. https://ccrweb.ca/sites/ccrweb.ca/files/static-

files/canadarefugeeshistory.htm (diakses Januari 28 , 2019).

"Canada's 2016 record high level of resettlement praised by UNHCR." UNHCR. t.thn. htwww.unhcr.org/news/press/2017/4/58fe15464/canadas-2016record-high-level-resettlement-praised-unhcr.html (diakses September 5 , 2018).

Canadian Council for Refugees. Safe Third Counntry. t.thn. http://www.ccrweb.ca/S3C.htm, (diakses Januari 28, 2019 ).

CBC News. Stephen Harper Suggest Canada Will Do More to Help Syrian Refugees. t.thn. https://www.cbc.ca/news/politics/canadaelection-2015-syria-refugee-canada-government-1.3221757 (diakses Maret 7,2019 ).

CIC. "Annual Tripartite Consultations On Resettlement." UNHCR.org. t.thn. https://www.unhcr.org/3cfb8a436.pdf (diakses Maret 6 , 2019).

Coyle, Jim. Weighing the costs and values of Canada's Syrian refugee pledge.

https://www.thestar.com/news/canada/2015/11/18/weighing-thecosts-and-values-of-canadas-syrian-refugee-pledge.html (diakses September 28, 2018). 
Dettmer, Jamie. Abaikan Pengungsi Suriah, Media kecam Negara Teluk. t.thn. https://www.voaindonesia.com/a/abaikan-pengungsisuriah-media-kecam-negara-teluk-/2959784.html

(diakses Desember 26,2018 ).

Dion, David Dodge dan Richard. Economic Performance And Policy During Harper Years. t.thn. http://policyoptions.irpp.org/magazines/october-2016/economicperformance-and-policy-during-the-harper-years/

(diakses Februari 21, 2019).

Dirks, Gerald E. Immigration Policy In Canada. t.thn. https:/www.thecanadianencyclopedia.ca/en/article/immigrationpolicy (diakses Januari 28, 2019).

Dobbin, Murray. Stephen Harper's Refugee Conundrum. t.thn. https://thetyee.ca/Opinion/2015/09/18/Stephen-Harper-RefugeeConundrum/ (diakses April 4 , 2019).

Duhaime.org . Duhaime's Law Dictionary. t.thn. http://www.duhaime.org/LegalDictionary/R/RuleofLaw.aspx (diakses Februari 21, 2019).

Government of Canada . Democracy And Human Rights. t.thn. https://www.canadainternational.gc.ca/eu-ue/policiespolitiques/democracy-democratie.aspx?lang=eng (diakses Februari 10, 2019).

Government of Canada. Canada's Economy. t.thn. https://www.canada.ca/en/immigration-refugeescitizenship/corporate/publications-manuals/discover-canada/readonline/canadas-economy.html (diakses Maret 8 , 2019).

- Immigration, Refugee, And Citizenship Canada Departmental Plan. t.thn. https://www.canada.ca/en/immigration-refugeescitizenship/corporate/publications-manuals/departmental-plan2018-2019/departmental-plan.html (diakses Februari 21, 2019).

hanggoro, Marcheilla. Jika di AS ditolak, Kanada justru terbuka pada pengungsi. 29 Januari 2017. https://www.merdeka.com/dunia/jikadi-as-ditolak-kanada-justru-terbuka-pada-pengungsi.html (diakses agustus 25,2018 ).

Hashem, Mohamed. A Haven No More: Canada's Cocervatives Refugee Policy. t.thn. https://www.aljazeera.com/indepth/features/2015/09/havencanada-conservative-refugee-policy-150915082517641.html (diakses Februari 21, 2019). 
John Mc Callum, Minister Of Immigration, Refuugee, And Citizenship. Canada has a proud history of doping The Rights thing for Refugees. t.thn. https://www.theglobeandmail.com/opinion/canada-has-a-proudhistory-of-doing-the-right-thing-for-refugees/article2747 (diakses Maret 13 , 2019).

Kelly, Dan. Immigrants are The Solution to Canada Labour Shortage. t.thn. https://www.cfib-fcei.ca/en/immigrants-are-solutioncanadas-labour-shortage (diakses Maret 8, 2019).

Keung, Nicholas. Court rules Denial Of Appeals for 'Safe Country' Refugees Unconstitutional. t.thn. https://www.thestar.com/news/immigration/2015/07/23/courtstrikes-down-ottawas-safe-country-list-for-refugees.html (diakses Februari 13 , 2019).

Kompasiana. 5 alasan penolakan bagi pengungsi Suriah. 15 September 2015.

https://www.kompasiana.com/selasarcom/55f26c18779773ce07a1f 99c/5-alasan-penolakan-bagi-pengungsi-suriah-irak?page=all (diakses Agustus 3, 2018).

Mashuri, Ikhwanul Kiram. Mengapa Pengungsi Muslim Timteng Lebih Memilih Eropa? t.thn. https://www.republika.co.id/berita/kolom/resonansi/15/09/14/nun ms4319-mengapa-pengungsi-muslim-timteng-lebih-memilih-eropa (diakses Desember 26 , 2018).

Minski, Amy. Canada to maintain immigration target, welcome 300,000 in 2017. t.thn. https://globalnews.ca/news/3036395/canada-tomaintain-immigration-target-welcome-300000-in-2017/ (diakses Februari 21, 2019).

Molnar, Petra. Response To The Syrian Refugee Crisis. t.thn. https://www.thecanadianencyclopedia.ca/en/article/canadianresponse-to-the-syrian-refugee-crisis (diakses Februari 14, 2019).

Monar, Irving Abella \& Petra. Refugees. t.thn. https://www.thecanadianencyclopedia.ca/en/article/refugees (diakses Januari 24 , 2019).

Muti'ah, Siti. "Pergolakan Panjang Suriah: Masih Adakah PanArabisme dan Pan-Islamisme?" Jurnal CMES, 2012: 5.

News Staff. Exclusive: Canadians Concerned Syrian Refugees Wills Strain Social Services. t.thn. https://toronto.citynews.ca/2015/12/10/exclusive-canadians- 
concerned-syrian-refugees-will-strain-social-services/

(diakses Februari 21, 2019).

OEC. Syria: Exports, Imports, Trade Partners. t.thn. https://atlas.media.mit.edu/en/profile/country/syr/ (diakses Maret $13,2019)$.

Parliament of Canada. An Introduction to How Canada's Parliament Works.

t.thn.

https://lop.parl.ca/About/Parliament/Education/ourcountryourparl iament/html_booklet/democracy-defined-e.html (diakses Februari 21, 2019).

-. Democracy Defined. t.thn. https://lop.parl.ca/About/Parliament/Education/ourcountryourparl iament/html_booklet/democracy-defined-e.html (diakses April 5, 2019).

"Press Release UNHCR." UNHCR. t.thn. www.unhcr.org/2015wrdpress-release (diakses Agustus 27 , 2018).

Press, Jordan. Reality Check: Does Trudeau Deserve All The Credit For Canada's Economic And Job Gains? t.thn. https://globalnews.ca/news/4795676/justin-trudeau-liberals-creditcanada-economy-jobs/ (diakses Februari 21, 2019).

The Canadian Press. Government says it never got refugee aplication from family of drowned Syrian boy. 3 september 2015. http://ottawacitizen.com/news/politics/relatives-of-dead-boysassail-canada-for-inaction (diakses Agustus 23, 2018).

- Father of Drowned Syrian Boy Blames Canada for Death of Wife And Son. t.thn. https://www.cbc.ca/news/world/father-of-drownedsyrian-boy-alan-kurdi-blames-canada-for-death-of-wife-and-son-

1.3223846 (diakses Februari 14, 2019).

Theglobaleconomy.com. Country Rankings. t.thn. https://www.theglobaleconomy.com/rankings/political_rights/ (diakses Januari 15, 2019).

Trew, Stuart. 5 Ways Harper Government Changed Canada. t.thn. http://behindthenumbers.ca/2015/10/16/5-ways-the-harpergovernment-changed-canada/ (diakses Februari 21, 2019).

Troath, Sian. "Prospects for Australian-Led Regional Cooperation on Asylum Seeker and Refugee Issues." Andalas Journal of International Studies. Vol. 5 No. 2, 2016: 109.

UNHCR. "Konvensi dan Protokol mengenai Status Pengungsi." UNHCR.org. t.thn. https://www.unhcr.org/id/wp- 
content/uploads/sites/42/2017/05/KonfensidanProtokol.pdf

(diakses Maret 6 , 2019).

—. "Syria regional refugee response." UNHCR. Sabtu Oktober 2018. https://data2.unhcr.org/en/situations/syria (diakses Agustus 4, 2018).

-. "Syria Regional Refugee Response." UNHCR Data. t.thn. https://data2.unhcr.org/en/situations/syri (diakses Januari 15, 2019).

-. "UNHCR Global Trends 2014." UNHCR.org. 2014. https://www.unhcr.org/551128679.pdf (diakses Januari 29, 2019).

-. "UNHCR Utatistic." UNHCR.org. t.thn. http://popstats.unhcr.org/en/overview (diakses Januari 15, 2019).

\section{Deklarasi Kepentingan yang Bertentangan}

Penulis menyatakan tidak ada potensi konflik kepentingan sehubungan dengan kepengarangan dan / atau publikasi artikel ini.

\section{Biografi}

Ressa Fatika Eldiati merupakan alumni dari jurusan Ilmu Hubungan Internasional Universitas Andalas. Minat penelitiannya adalah Uni Eropa dan Migrasi. Penulis dapat dihubungi melalui email: ressa_fatika@yahoo.com. 